European Journal of American Culture Volume 30 Number 3

O 2011 Intellect Ltd Article. English language. doi: 10.1386/ejac.30.3.175_1

\title{
The senses of Muriel Rukeyser's The Book of the Dead ${ }^{1}$
}

\section{ABSTRACT}

When Muriel Rukeyser travelled to Gauley Bridge in 1936 to report on the industrial disaster that had led to the deaths of over 700 miners, her findings led her to write what is arguably her masterpiece - the 1938 poem series The Book of the Dead. Of all Rukeyser's writings, this hybrid work of documentary techniques and metaphors, of testimony and elegy, has attracted the most critical attention. However, analyses of the series have tended to focus on the ways in which the poet adopted and adapted documentary methods in order to offer a leftist ideological critique on capitalist-born social injustice. The purpose of this article is not to negate such readings, but to offer alongside them insight into a more ethical-philosophical approach that I believe guided Rukeyser's entire career. Via an examination of the ways in which Rukeyser employs the human senses to articulate the complexities of human political, metaphysical and social relations, this article explores the influence of the Zionist Martin Buber on the poet. Rukeyser acknowledged Buber's writings in her later work, but I contend here that they played a large part in the formation of her poetics, especially in connection with her documentary aesthetic. Whilst several critics have noted, albeit often superficially, the Marxist flavour of Rukeyser's poetry in The Book of the Dead, I argue for the influence of Buber over Marx in terms or responsibility, community and dialogue. ${ }^{2}$ Both Rukeyser's and Buber's methods of expressing and promoting these ethical necessities rely on a synaesthetic response to the world. Where Buber advances $a$
\end{abstract}

\section{KEYWORDS}

senses

ethical

creation

exchange

synaesthetic

witness

1. This article is an extended version of a paper I presented at the 17th Annual English and American Literature Association Conference, held at Soochow University, Taipei, Taiwan, in November 2009 , whose theme was 'literature and the senses?

2. Although a Marxist reading of Rukeyser is entirely possible, it should be noted that it 
is not entirely helpful. Rukeyser was careful not to align her poetics with a specific political stance throughout her life, maintaining instead a combination of (at times, particularly Jewish) mysticism and a popular front anti-fascism and anticapitalism. For more on this subject, read Alan Wald (2002)

3. Several hundred workers were migrant workers, the majority of whom were black, from several different States, many of them southern.

4. Rukeyser's involvement in documentary modes and movements included work in film, radio, magazines, poetry and fiction. dialogue between the self and alterity through transcendent personal encounter, Rukeyser locates such encounter in the poem, arguing for an exchange that leads to creation, and to personal and interpersonal growth.

In 1936, the Jewish American poet Muriel Rukeyser travelled to Gauley Bridge, West Virginia, to report on one of the worst industrial disasters in America. Perhaps her most well-known work, The Book of the Dead (published in the collection U.S.1 in 1938), was the result: a poetic rendering of the story of the town that lost over 200 of its community to occupational silicosis. ${ }^{3}$ Utilizing several documentary modes and styles popular to the era, Rukeyser created a montage of voices, narratives and images, threaded through with quotations from the Egyptian Book of the Dead, whose message of rebirth and regeneration was imperative to Rukeyser's understanding of the future of American political and social life. This essay will acknowledge Rukeyser's use of the documentary, highlighting the Marxist influence on her poetry, but suggest that the ethical theory of the Jewish philosopher Martin Buber is more closely aligned to Rukeyser's own poetics of meeting and dialogue. This affinity is most clearly apparent in her employment of and recourse to the human senses - explicated in her poetic treatise The Life of Poetry and demonstrated in her poem series The Book of the Dead. The majority of scholarly writings addressing The Book of the Dead have explored the work's modern aspects in terms of its technical and political specificity. This essay, therefore, argues for a more ethical philosophical reading of The Book of the Dead than has hitherto been considered.

\section{MURIEL RUKEYSER AND MARTIN BUBER}

In the late 1930s, Rukeyser forged a relational poetics that would inform the rest of her career. Her influence by and involvement in the prevalent documentary mode of political and artistic expression in the 1930s allowed Rukeyser a means by which to experiment with methods of exploring selfhood as well as social injustice. ${ }^{4}$ Addressing the ethical, political and ontological issues generated by the social realities of the time, she insisted on the necessity of poetry as 'a meeting-place' between ostensibly separate fields of discourse and discipline - between art and science, imagination and practice, the self and others, the personal and the political: 'there is a meetingplace between all the (sic) kinds of imagination. Poetry can provide that meeting-place' (Rukeyser [1949] 1996: xi). For Rukeyser, the poem's status as a meeting-place was due largely to its potential to engender connection via shared sensual experience. Her influences for this are several, and include the Biographia Literaria of Samuel Taylor Coleridge, ancient Hebrew poetry, a profound involvement with various modern visual arts such as theatre and film, and a keen interest in the philosophy of Martin Buber.

Rukeyser acknowledged the influence of Buber's thought on her own poetics and faith in 1960, when her long sequence poem 'Akiba' - one of her 'Lives' poems, telling the story of the first- and second-century scholar and Rabbi - was serialized in the publication American Judaism. Commenting on her extensive reading of Buber's writings and biography, Rukeyser not only drew parallels between Buber's ethical philosophy and her own thinking, but asserted that the sources for the first part of 'Akiba', entitled 'The Way Out', were 'from stories of the Exodus and the desert, of American history and our own times' (Rukeyser 1961: 13). The near history of America's own 
Dust Bowl migration, perhaps best documented in words and photographs by the photographer Dorothea Lange and the sociologist Paul Taylor in American Exodus (1939), appears to have (still) informed Rukeyser's writing some twenty years later, meeting in the poet's imagination with contemporary events in America and abroad - the 1956 Suez Crisis, for example, and Israel's apprehension and extradition of Adolph Eichmann from Argentina in 1960. ${ }^{5}$

However, it would seem that Buber influenced Rukeyser significantly earlier than the late 1950s. Buber's Ich und Du, published in 1923 in Germany and translated as $I$ and Thou in the English publication in 1937, structures religious and social philosophy upon a general belief in the potential for intersubjective creativity within relationship and dialogue, situating human beings in dialogic relations with other human beings and ultimately with God. Via a commitment to strong, interpersonal associations, a human transcends institutionalized and formalized frameworks in order to reach a more sacred realm of intercourse. A dialogue between humankind and God combines with an inner dialogue of the self, giving rise to the crystallization of a common discourse, which in turn is essential for social cohesiveness. Buber called this transcendent dialogue a 'meeting' between consciousnesses (Buber 1956: 43-62). In Between Man and Man ([1936 trans. 1947], 2004), Buber developed his theory of 'meeting', highlighting his belief in the necessity of self-reflection to the 'philosophical knowledge of man'. In discussing what he termed 'philosophical anthropology', Buber proposes that

everything that is discovered about historical and modern man [...] must be built up and crystallised round what the philosopher discovers by reflecting about himself. [...] He can know the wholeness of the person and through it the wholeness of man only when he does not leave his subjectivity out and does not remain the untouched observer.

(Buber 1992: 34)
5. Janet Kaufman notes the 'significant' timing of 'Akiba' for Jewish history (Kaufman 1999: 53).

The philosopher/anthropologist must therefore engage the senses holistically as both a participant and an observer in human relations, in order to understand such relations. The Lockean notion of an awareness of the self's place in the world via one's sensual experience of it is evident in Buber's dialogical and ethical 'wholeness of man', which he nevertheless argues is in opposition both to individualism (which 'sees man only in relation to himself') and collectivism (which 'does not see man at all, it only sees "society." ') (Buber 1992: 36, emphasis in original). The 'fundamental fact of human existence', Buber argues, is 'rooted in one being turning to another'. This communication exists in its own sphere, which Buber terms 'the sphere of the "between" ': a sphere in which 'an "outer" event and an "inner" impression' (again, in an adaptation of British empiricist notions - here, those of Hume) come together to create a 'third alternative' (Buber 1992: 39). Buber provides an example:

In the darkened opera-house there can be established between two of the audience, who do not know one another, and who are listening in the same purity and with the same intensity to the music of Mozart, a relation which is scarcely perceptible and yet is one of elemental dialogue [...].

(Buber 1992: 40)

The 'sphere of the "between" ' exists in moments in which two realms overlap to create and share a third realm of experience: an engagement of one's 
6. I can find no evidence that Rukeyser read Buber's Between Man and Man before writing her own example of dialogic encounter, and as The Life of Poetry was the result of a lecture series given in the years mmediately preceding its publication, it is highly unlikely that she had encountered this example of Buber's writing at the time of her own. The concerns, ideas and ideals expressed in Buber, however, are remarkably similar to Rukeyser's - a parallel marked clearly by their shared religion. physical senses that leads to an awareness of the presence of an 'other', and a shared, wordless 'dialogue'. According to Buber, this is where 'I and Thou meet [...] the realm of the between' (Buber 1992: 4o, emphasis in original). Buber proposed that his theory may constitute the starting point to 'an advance' towards a 'transformed understanding of the person and [...] of community', concluding that the meeting 'of the One with the Other' represents an initial position from which to answer the question of 'what man is' (Buber 1992: 41).

Rukeyser's notion of the poem as place of 'meeting' and creative exchange is best explicated in her treatise The Life of Poetry (1949), in which her use of theatrical metaphor is strikingly similar to Buber's:

You sit beside me in the house dark, with the light thrown from the stage on your face, and shadows at your back. When you laugh, I feel it, and I feel the man in front of me [...] But we are not separate from the play [...] We sit here, very different from each other, until the passion arrives to give us our equality, and to make us part of the play, to make the play a part of us. An exchange is being effected. ${ }^{6}$

(Rukeyser [1949] 1996: 174)

This human encounter, written in deliberately inclusive language, is described by Rukeyser in explicitly synaesthetic terms. Situated in the dark, the faces of the audience are illuminated by 'light thrown from the stage'. As 'you' laugh, ' $T$ ' not only hear, but 'feel it'. The spectacle of the drama being played out in front of us facilitates between us a wordless 'exchange', as we observe and participate in the 'passion' emanating from the stage. The 'difference' between one audience member and the next - your status as 'other' - is in turn absorbed into a reciprocal relation whereby alterity is acknowledged, but recognized and re-termed as 'equality'. For Rukeyser, such moments of human exchange - flashes of sensual and sensorial experience she terms 'moments of proof - result in creation: the genesis and genius of poetry.

Exchange is creation. In poetry, the exchange is one of energy. Human energy is transferred, and from the poem it reaches the reader. Human energy, which is consciousness, the capacity to produce change in existing conditions.

(Rukeyser [1949] 1996: 173)

For both Buber and Rukeyser then, the creative, dialogic exchange that occurs in such realms of dialogic 'meeting' has the capacity not only to facilitate 'wholeness' via self-reflection, but to make changes to existing social systems. As I hope to demonstrate, creative exchange, and a social and spiritual cohesion closely aligned with the philosophy of Buber, is intrinsically connected in Rukeyser's poetry, where a full engagement of the human senses has the potential to result in a representation of reality that combines the political and the poetic, the documentary and the subjective, the outwardly observational and the introspective.

\section{THE 1930 S AND DOCUMENTARY}

The ethical dynamic to Rukeyser's poetics, exemplified in her emphasis on poetry's power to equalize via encounter and to 'produce change' via the concomitant relation of energy exchange, is particularly apposite when 
considering her leftist poetry of the 1930s and 1940s. During this era, the documentary movement flourished in American literature and culture as the principle means of communicating the social and personal realities of a nation in crisis. Rukeyser, sensitive to such realities, soon became deeply involved with the modes, ideologies and techniques of documentary, working in film, photography and reportage, and manipulating their methods in her poetry. In the late 1930s, her writing was informed by several documentary modes, two of which, with their overt reliance on the synaesthetic employment of the human senses, concern me here: the road narrative/travel guidebook, and the reportage of the participant-observer.

Road narratives proliferated in 1930 s American literature, both as a result of investigative reporting into the effects of the Depression and as a more personal effort on the part of writers to understand the physical and human geography of America first-hand. Sherwood Anderson's Puzzled America (1935) and James Rorty's Where Life Is Better (1936) are two examples of, what William Stott later labelled, 'I've Seen America' books - semi-autobiographical works of travel reportage that sought to re-establish identification with the landscape as well as highlight those aspects of the country that rendered it uniquely 'American' (Stott 1973: 242). These texts were informed by a distinctly Whitmanian impulse to travel the country - to incorporate and give voice to all human (American) experience via a poetics of witness and sensual participation.

In 1937 as part of the New Deal work initiative, the Works Progress Administration (WPA) began a series of 'American Guides', providing detailed histories and geographies of the states. Tracing the cultural and political history of America along a written route map or 'tour', the Guides offered the reader a vast catalogue of facts and figures regarding the state's economic, geographic and demographic makeup and indicating several 'historic spots', either on or visible from the road, at which the reader/ traveller was encouraged to pause to 'connect the present with the past' (Hatcher 1938: 247). The offshoot Highway Guide Series proved equally as popular, further tracing the country's cultural lineage by reasserting a specifically American tradition of mobility and progress. Rukeyser's second book of poems, U.S.1 (1938), named after the US highway spanning the East Coast, shares its title with the WPA Highway Guide published the same year. ${ }^{7}$ In it is published what is arguably Rukeyser's poetic masterpiece: the poem series The Book of the Dead, in which Rukeyser both engages with and challenges the rhetoric, aesthetics and ideologies of the documentary mode, offering her own guided tour of an area of West Virginia, charting its historical trajectory as a site of natural beauty and social practice.

Rukeyser's text also responds to political and technical complexities of the participant/observer trend in written and photographic reportage. The 1930s documentary trends of observation and representation - of which Lange and Taylor's American Exodus and Margaret Bourke-White and Erskine Caldwell's You Have Seen Their Faces (1937) are two photo-textual examples - gradually began to raise questions concerning the validity of such representation on a social and ethical scale. As reporters and photographers conducted fieldwork that often involved stage-managing a shot for dramatic effect, or recording a person's image but not their name or words, documentary methods risked objectifying and patronizing those people whose lives were being documented. ${ }^{8}$ Rukeyser appears to have been acutely aware of this dilemma. Her insistence on using the word 'witness' when describing poetry expresses the relationship
7. Although the fact that the two books were published within a month of each other excludes the possibility of Rukeyser adopting the name of the Guide for her poetry, their close publication indicates the ideological confluence of Rukeyser's work with the WPA Guides.

8. Margaret Bourke-White is one documentary photographer whose methods have come under such scrutiny. See Rabinowitz (1994). 
she hoped to achieve in the poetic act of bringing together, and is again strikingly similar to Buber's religious-ethical notion that the 'wholeness' of humanity may be arrived at if one does not remain the 'untouched observer':

I should like to use another word: 'audience' or 'reader' or 'listener' seems inadequate. I suggest the old word 'witness,' which includes the act of seeing and knowing by personal experience, as well as the act of giving evidence. The overtone of responsibility in this word is not present in the others; and the tension of the law makes a climate here which is that climate of excitement and revelation giving air to the work of art, announcing with the poem that we are about to change, that work is being done on the self.

(Rukeyser [1949] 1996: 175)

The complexity of this extract from The Life of Poetry requires careful analysis. Rukeyser's employment of 'the old word' attributes to it a synaesthetic significance that draws on Old Testament scripture, religious experience, legal rhetoric and ethical and cognitive systems of philosophy. The term is both an utterance and an 'act', passive and active; an original, dialogical, perhaps even holy word that necessarily explores the ethical position of the other as a precondition of self-knowledge. Theorizing that 'work' may be 'done on the self' via the assumption of 'responsibility' for something outside the self, Rukeyser sees this 'responsibility' as resulting from a sensory and cognitive 'personal experience' of the other. That 'seeing or knowing' can lead to 'giving' conjoins the realm of the courtroom with the more elemental realm of dialogic encounter for Rukeyser, whose use of the word 'revelation' further indicates the religiosity of the 'climate' produced. This climate in turn is the 'meeting-place' of creative exchange - Buber's 'sphere of the "between"' - which, 'giving air to the work of art', 'announc[es] with the poem' (both the product and the cause of such creation) the imminence of 'change' to human consciousness and interpersonal relations, denoted characteristically by Rukeyser by the inclusive pronoun 'we'. This passage (the general importance of which has been noted by Rukeyser scholars, but the depth of which has not been adequately explored) is particularly significant when considering The Book of the Dead.

\section{The Book of the Dead}

In 1936, Rukeyser and her friend, the photographer Nancy Naumburg, travelled to report on an industrial disaster at Gauley Bridge, West Virginia. In the process of tunnelling to divert water from a river to a nearby power station, vast deposits of over 90 per cent silica had been discovered in the rock. The tunnels had consequently been widened to become mines, but in their rush to collect the valuable silica, the controlling companies had not provided their workers with proper safety equipment, resulting in the deaths of hundreds from occupational silicosis. The Book of the Dead is Rukeyser's response to and record of the people and the landscape involved. The initial lines of its opening poem, 'The Road', both appeal to popular modes of documentary and travel writing, and establish a realm of shared interest and communication in which poet, poem and reader/witness meet.

These are roads to take when you think of your country and interested bring down the maps again, 
phoning the statistician, asking the dear friend, reading the papers with morning inquiry.

(Rukeyser 2006: 73)

The determiner 'these' implies Rukeyser's own familiarity with the 'roads' to which she directs her reader/witness, and the direct address both engages us and imparts a sense of patriotic responsibility. The visualization of the roads is instant and instantiated by imagination: when we 'think' of our country, we are impelled to 'take' these literal and figurative paths of enquiry, and Rukeyser's use of 'when' rather than 'if' virtually disallows us the choice of inaction - indeed, the continuous form of the following three verbs connotes our engaged activity. However, a little further along the poem and off the 'well-travelled, six-lane highway', we are no longer driving but being driven into a less civilized landscape whose strong link with the past is connoted by the fact that one must go 'back' to reach it:

These roads will take you into your own country.

Select the mountains, follow rivers back,

travel the passes. Touch West Virginia [...]

Choosing a path away from the tarmac, the traveller experiences the country in an approach that is participatory as well as observational. As a haptic connection with the land apparently takes place, indicated by the imperative start of a new sentence mid-line, the tourist takes the first step to becoming and bearing witness. The resultant relations with 'West Virginia' as state and as poem will involve the physical and ethical touching of the physical body and the metaphysical self by the other, through dialogic relation. Yet such proximity comes after a more distant observation. On a lookout, the poet/ guide and her photographer companion come to rest as the poem ends:

Now the photographer unpacks camera and case, surveying the deep country, follows discovery viewing on groundglass an inverted image.

John Marshall named the rock (steep pines, a drop he reckoned in 1812, called) Marshall's Pillar,

but later, Hawk's Nest. Here is your road, tying

you to its meanings: gorge, boulder, precipice.

Telescoped down, the hard and stone-green river cutting fast and direct into the town.

(Rukeyser 2006: 74)

As the road assumes organic shape, a strong relationship between the witness and the landscape is finally established. With possession ('your road') comes unavoidable responsibility (to use both Rukeyser's and Buber's terminology), and the witness has now become a component of the road's historical significance.

The privileged visual perspective we, as tourists, are afforded by the lofty Hawk's Nest is both underscored and undermined by the camera's telescopic power. A vital tool to documentary expression, the camera during the time represented a method of recording visual veracity, a correlative of the eye of the beholder and a selective framing device. ${ }^{9}$ At the end of the first of many
9. Writer James Agee, for example, called the camera 'the central instrument of our time', incapable of recording anything but absolute, dry truth' (Agee [1941] 2001: 24, 212). 
10. Written in the spring of 1845 , under the title "1) ad Feuerbach"; Marx's original text was first published in 1924, in German and in Russian translation, by the Institute of Marxism-Leninism in Marx-Engels Archives, Book I, Moscow. The English translation was first published in the Lawrence and Wishart edition of The German Ideology in 1938. It is available online at: http://www.marxists. org/archive/marx/ works/1845/theses/ index.htm last accessed 30.10.2011.

11 Fredric Jameson, Raymond Williams and Marxist critic Terry Eagleton are three such scholars to debate the metaphor. See Mitchel (1986, chapter 6).

12. An excellent analysis of the figure of the camera obscura in Marxist can be found in Mitchell (1986). roads to weave through The Book of the Dead, Rukeyser presents us with an ambiguous image. The 'photographer', whose very act of 'unpacking' suggests her status as traveller or tourist, views an 'inverted image' via a mechanism that further emphasizes optically the physical and social distance between herself and her photographic subject. Rukeyser, whose quest to Gauley Bridge was to highlight the injustice of its imbalanced social relations, here appears to employ the camera obscura as a symbol of the unsettled state of historical conditions and their social truths, simultaneously alluding to her own position, and that of her 'photographer' friend, within a complex network of power relations.

In The German Ideology ([1845-6] 1932), Karl Marx employed the camera obscura as pejorative metaphor in the critique of 'false consciousness', claiming that an inversion of material conditions and their social truths was the result of 'historical life-process' (Marx and Engels 1998: 42). Rukeyser's use of this image has been seen as an allusion to Marx's metaphor by more than one scholar (e.g. Kalaidjian 1991-92; Wechsler 1999); however, as the first English translation of The German Ideology was published in 1938, ${ }^{10}$ and Rukeyser's U.S.1 was published in January of the same year, this is very unlikely to be the case. The metaphor is itself highly problematic, and has caused a substantial amount of debate in Marxist theory; ${ }^{11}$ Marx's criticism is directed towards 'all [German] ideology', in which, he argues, 'men and their relations appear upside down as in a camera obscura' (Marx and Engels 1998: 42). Complications arise as soon as one contemplates the metaphor's effectiveness in postulating ideology as generating a system of distorted images - the question of the existence of, and access to, 'real' images or representations of the world, for example, is unanswered.

Leaving aside such problems, it seems more relevant to note Rukeyser's adoption of an optical symbolism that, whilst characteristic of modernist discourse and writing, assumed particular significance during the Depression decade in 'radical' and 'conservative' writings alike. The utilization of the camera as metaphor in documentary writing was common during this time, and leftist writers such as Rukeyser often employed a Marxist standpoint when reporting on the realities of social injustice. While this conflation of Marxism with visual rhetoric continues to infuse theories of ideology, ${ }^{12}$ it became a potent documentary tool during the late 1930s and early 1940s. As Paula Rabinowitz has commented, 'Marx's famous chide to the French peasantry "they cannot represent themselves; they must be represented" [...] provides an early example of documentary reportage' (Rabinowitz 1994: 10).

However, Marx states that the 'upside-down' nature of the relations of men in ideology 'arises just as much from their historical life-process as the inversion of objects on the retina does from their physical life-process' (Marx and Engels 1998: 42). History - or at least the human race's view or version of it - is thus linked intrinsically to the immediate physical sense of sight, as well as to a mechanical manipulation of it. As W. J. T. Mitchell has commented, Marx's dismissal of German idealism and his eventual dissatisfaction with empiricism led him to conclude that historical materialism was the most effective way of avoiding 'a positive empiricism that stands outside the historical life process, and a negative idealism that can only play with shadows, phantoms and chimeras' (Mitchell 1986: 174). According to Marx, by re-visualizing and recounting the material history of production and exchange, we describe an 'active life-process', by which 'history ceases to be a collection of dead facts as it is with the empiricists (themselves still abstract), or an imagined activity of 
imagined subjects, as with the idealists' (Marx and Engels 1998: 43). This type of commodity 'exchange' is certainly not what Rukeyser had in mind when describing the poem as a 'meeting-place'; however, I wish to argue that by recounting the 'active life-process' of the people and events of Gauley Bridge, Rukeyser traces a path that revivifies the landscape and its dead via dialogic 'witness'. As reader/travellers, for example, we are indicated the history of the place by reference to the person who named it more than a century before ('John Marshall'), and through such identification, we become 'tied to its meanings'. It is thus with heavy sarcasm that Rukeyser describes, en route,

[...] the wealthy valley, resorts, the chalk hotel.

Pillars and fairway; spa; White Sulpur Springs.

Airport. Gay blank rich faces wishing to add

history to ballrooms, tradition to the first tee.

(Rukeyser 2006: 73)

The pastimes of such a class of people represent a passivity that is further indicated by their 'blank' faces, which contrast with the 'fierce' natural features of the country described in a subsequent stanza. Similar to Marx, Rukeyser implies that true history cannot be read through such a life process, and whilst the 'rich' employ the landscape as passive background to their bourgeois hobbies, Rukeyser views it as site and component of social and historical activity. As the poet charts a path through the American landscape in search of the truth, she pauses along the way to 'connect the present with the past' via both a sensual reimagining of history and a visual articulation of current realities. We 'touch', 'view' and 'look' at West Virginia, 'seeing it as a product of "historical life-process" and not as a simple datum presented to the senses' (Mitchell 1986: 175).

In the second poem, 'West Virginia', the reader is guided on a concise tour of the state and its history. Visual images of the historical landscape feed the imagination, and are tethered to concepts of first contact, and the hope intrinsic to discovery. Marxist sentiment is again invoked as Rukeyser juxtaposes an image of the English colonists tracking into the wilderness with an Indian guide and 'indentured' servant, with the site of the execution of John Brown, whose capitalized name alludes to the importance of revolution in both local and national history. West Virginia as state and as poem becomes a meetingplace of past and present, of the dead, the living and what Rukeyser terms elsewhere as the 'future-born', linked by the constant and regenerative power of the river that runs through it:

But it was always the water the power flying deep green rivers cut the rock rapids boiled down, a scene of power.

Done by the dead.

Discovery learned it.

And the living?

Live country filling west,

knotted the glassy rivers; 
like valleys, opening mines,

coming to life.

The rivers, meeting in knots and spreading throughout the countryside, create connection as the 'wealthy valley' seen previously from the road gives way to 'opening mines, coming to life'. Again, this revivification of American sites of imagination and social practice appears to allude to Marxist concepts of land ownership that is shared, open to all and not separated into different lines of ideological and geographical stratification. The pun on the possessive pronoun situates the deadly 'mines' in a new dynamic of visible openness and birth, whereby those who have been destroyed by capitalist power relations are able to teach the living the meaning of 'discovery' and the futility of possession. Nevertheless, Rukeyser's subtle rhetoric of responsibility rather than culpability here owes more to Buberian ethical philosophy than to Marxist thought, and hints at an inclusive dialogism that becomes the underlying force of The Book of the Dead.

The connective rivers, however, are 'glassy', recalling both the 'groundglass' template of the camera and the glistening appeal of the silica embedded in the 'mines'. Indeed, glass emerges as a recurrent trope throughout the poem series. In the poem 'Gauley Bridge', the camera serves as an initial framing device for the scene that unfolds. Placed 'at the crossing', the camera records the town again from a position of privilege: a meeting-place of roads as well as the point at which multiple pathways diverge. The glass of the template extends to symbolize a plurality of meanings as 'the camera eye' tracks across the visual details of the town. It is figured in the 'empty windows' of the street, in the 'April-glass-tinted' waitress serving tourists on a bus tour of the highway, the 'coast-to-coast schedule' of which is displayed behind 'the plateglass window' of the cafe. Via the modern trope of glass, the quotidian workings of commerce, consumerism and spectatorship are brought to the surface of the witness/traveller's consciousness:

Railway tracks here and many panes of glass

tin under light, the grey shine of towns and forests:

in the commercial hotel (Switzerland of America)

the owner is keeping his books behind the public glass.

Post office window, a hive of private boxes,

the hand of the man who withdraws, the woman who reaches her hand and the tall coughing man stamping an envelope.

(Rukeyser 2006: 77)

The transparent medium of glass becomes a 'public' symbol of Marxist reification, economic relations and separation. 'Each of [man's] human relations to the world -', wrote Marx, 'seeing, hearing, smelling, tasting, feeling, thinking, observing, experiencing, wanting, acting, loving - in short, all the organs of his individual being [...] are the appropriation of human reality.' Marx contended that 'private property has made us so stupid and one-sided that an object is only ours when we have it - when it exists for us as capital, or when it is directly possessed, eaten, drunk, worn, inhabited, etc.' Therefore, he argued, 'in the place of all physical and mental senses there has come the sheer estrangement of all the senses, the sense of having' (Marx 1981: 94 , emphasis in original). Under a capitalist system, this 'estrangement', also 
termed 'alienation', extends from the human senses to the worker's position in relation to herself/himself; to other workers; to the product; and to the act of production. Most importantly, however, the individual finds himself/ herself estranged from his/her own 'species essence' - that natural quality that renders us human. According to Marx, as human beings are motivated at a fundamental level by their relation to the world through their senses, when this relation is compromised, one becomes estranged from oneself. When Marx wrote that 'the forming of the five senses is a labour of the entire history of the world down to the present', he expressed his belief that the development of the senses was not ontologically innate, but the result of historical processes; thus, 'the psychic structures which are derived from this organization of the senses by the objective conditions of production' might also be seen as pre-eminently historical (Marx 1981: 96, 97, emphasis in original).

In 'Gauley Bridge', economic relations appear to have replaced sensual ones. The effect of the mining disaster, itself the result of corporate, capitalist greed, is the partition and closure of human senses; their separation from each other further serving to separate the townspeople, who function in this poem as instruments, defined by their roles in production: keeping books, serving food and stamping envelopes. The hand of the man who 'withdraws', for example (and the ambiguity of the word in reference to either a financial or physical and emotional withdrawal is surely intentional), appears to miss the haptic connection of the woman's reaching hand. Elsewhere, 'the waitress and the yellow apron' are objectified by 'one's harsh night eyes over the beerglass', while throughout the town, glass windows divide the people, creating 'a hive of private

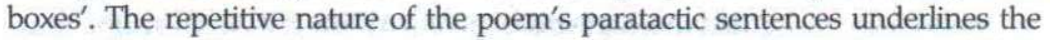
strata of separation - between the townspeople, between the workers and their various thankless labours, and between the reader and the people described. We are presented with a network of visual relations that have lost their connective ability, serving instead to objectify and separate the community:

Eyes of the tourist house, red-and-white filling station, the eyes of the Negro, looking down the track,

hotel-man and hotel, cafeteria, camera.

(Rukeyser 2006: 78)

Through the flat, documentary tone and tread of the lines, Rukeyser provides a series of snapshots of Gauley Bridge that emphasize the controlling forces of privatization, reinforced by lexis such as 'commercial', 'owner', 'keeping', 'deserted' and 'empty'.

The proliferation of glass at Gauley Bridge is thus a sign of both industrial progress and the dangers of social segregation that such progress might enforce. Rukeyser's imagery in this poem is stylistically and quietly photographic, recalling the austere urban compositions of the documentary photographer Walker Evans, whose influential collection American Photographs was published the same year as U.S.1 .. Evans' photographs of roadside billboards and gas stations, municipal buildings and torn movie posters are evoked throughout, for example in the seventh stanza:

Glass, wood, and naked eye: the movie-house

Closed for the afternoon frames posters streaked with rain,

Advertise 'Racing Luck' and 'Hitch-Hike Lady.'

(Rukeyser 2006: 78) 
13. Friedman quotes Buber's Between Man and Man, 'Dialogue'
Yet the emphasis on the senses in this poem, particularly that of sight, extends to the reader's position both as engaged 'witness' and as removed other, whose own view of the inverted relations, we must remember, is framed by the way in which the 'camera at the crossing sees the city' in the poem's initial line. Rukeyser is performing the role of guide and interlocutor here, returning to the direct address she employed earlier in 'The Road', and infusing it with an urgency that demands at least an emotional response to unexpected alterity: 'What do you want - a cliff over a city?' The various billboards, signs, signals and symbols that are captured by the 'camera eye', 'the eyes of the Negro', 'the naked eye', 'one's harsh night eyes' and particularly the 'eyes of the tourist house' alert us to the necessity of dialogue in a town where social cohesion has apparently disintegrated, replaced by objectifying observation.

Buber's understanding of dialogic relations portrays total moral action in terms of 'becoming aware' of 'signs' and responding to them. For Buber, similar to Rukeyser, 'response' and responsibility are inextricable; our social and moral duty is to meet 'signs' - for Buber, those objects that we do not simply 'observe', but allow to 'say' something to us - by becoming 'open' to them. As Maurice Friedman, a Buber scholar on whom Rukeyser was later to rely, has explained,

This 'saying' is thus nothing other than the 'I-Thou' relation whether it be the full, reciprocal I-Thou relation between men or the less complete and non-reciprocal relation with nature or in artistic creation and appreciation. Our inherited mechanisms of defence protect us from seeing the signs as really addressing us. 'Becoming aware' is the 'openness' which puts aside this perfected shell in favour of true presentness.

(Friedman 1955: 167-8) ${ }^{13}$

For Rukeyser, this 'becoming aware' was the potential result of the relations generated by poetic 'witness', by the poem as 'meeting-place' and by the camera. Seeing the city's signs, the camera functions in 'Gauley Bridge' indeed throughout The Book of the Dead - as both an instrument of proof and armament in crisis. In the concluding poem, entitled 'The Book of the Dead', Rukeyser situates the figure of the camera as a new mechanism of awareness to replace those 'inherited mechanisms of defence' that have hitherto prevented true 'presentness': 'Defense is sight', she writes, 'widen the lens and see [...] new signals, processes' (Rukeyser 2006: 110). The inverted images of Marx's figurative camera obscura, apparently the result of 'historical life-process', are here turned on their head. Rukeyser uses the camera, as fact and as metaphor, to right misperceptions and to allow for unobstructed reciprocity between self and other: to enable the witness 'to see the signs as really addressing us':

Carry abroad the urgent need, the scene, to photograph and to extend the voice, to speak this meaning.

Voices speak to us directly. As we move. As we enrich, growing in larger motion, this word, this power.

[...] 
[...] Name and road, communication to these many men, as epilogue, seeds of unending love.

(Rukeyser 2006: 110-11)

The 'voices' are those of the dead, their message spoken to 'us', as witnesses to the poem, via a communication that both synthesizes and transcends the human senses - most notably, hearing and seeing. Response and responsibility are clearly linked in Rukeyser's final invocation to ethical action; by viewing and photographing 'the scene', we 'carry' it (as opposed to simply sending it) beyond our own sphere, extending the voice of the other with our own at the same time as we are spoken to directly. The identities and journeys of those whose lives have constructed the historical processes of West Virginia conjoin with our own given and taken 'name and road' to form an elemental 'communication' that constitutes the starting point of 'unending love'. The religious tone to the final two words of the poem series, and the reciprocity of the relationship between 'many men' denoted in these closing stanzas, indicates a closeness to the dialogic human relationship explicated in Buber's I and Thou and Between Man and Man, which itself leads to a communication with the eternal love of God (Buber 1956, 1992).

The evident mysticism of this poem, reminiscent of that of Buber, as well as evoking the rituals and death rites of the ancient Egyptians, occurs intermittently throughout The Book of the Dead, and is in apparent contrast to the stark, documentary tone of poems such as 'The Disease' and several sections of 'Praise of the Committee'. The latter poem incorporates the Marxist concept of workers' unification in revolutionary action against their oppressors, although the blend of spiritual lyricism and ethical realism towards the poem's conclusion again points to a more religious social structuring. Calling for a socialist reconfiguration of society, Buber stressed the danger of confusing 'social' and the 'political' principles. For Buber, the 'social principle' is commensurate with the dialogical, while the 'political' refers to the ordered world of ' $\mathrm{It}^{\prime}$ - the subjective world that human beings experience only within themselves, and lacking in any mutuality (Buber 1951: 5). Social restructuring is essential because capitalism is inherently poor at generating 'organic community', and Marxist socialist means of remedy - unity and centralization - cannot engender multiplicity and freedom (Buber 1951: 5). According to Buber, real socialism calls up a deep-rooted community from shared memories, traditions, languages and experiences - realities that have been buried by the state. As I argue below, the unearthing effect of Rukeyser's poetry is indicative of a poetics that invariably promotes social and ethical inclusion, rather than inculcate exclusion, either of the other or the self something Buber argued that the Marxist movement inevitably led to. ${ }^{14}$

'Praise of the Committee' represents the merging of documentary observation and lyrical expression, in which dialogic relations arise from a Marxist move to unite and revolt. In contrast to 'Gauley Bridge', 'Praise of the Committee' figures a meeting of those afflicted by the disaster. Gathering whenever and wherever they can, the townspeople form a united group of individual voices speaking as one force against their oppressors. Their meeting-place is unfixed, and changeable:

Here in the noise, loud belts of the shoe-repair shop, meeting around the stove beneath the one bulb hanging.
14. Buber's problems with Marxist theory are founded on his understanding of it as essentially exclusive. See Friedman (1955: $116,125-28,210)$ 
They come late in the day. Many come with them who pack the hall, wait in the thorough dark.

This is a meeting-place of wills and senses, where a creative exchange of energy takes place in terms similar to Rukeyser's exposition of the moment in a darkened theatre. Here, however, stage lights are replaced by a single bulb, and laughter is replaced by 'the cough of habit' and the mechanical noises of quotidian labour. This poem is also inscribed as a site of both visual and emotional witness: 'This is a defense committee', writes Rukeyser, anticipating her later assertion that 'defense is sight', and highlighting the need for a mode of looking that involves participation as well as observation.

The effect of the poem, therefore, is not empathy but reciprocity. For Buber, genuine dialogue can be either spoken or silent, as its essence lies in the fact that 'each of the participants really has in mind the other or others in their present and particular being and turns to them with the intention of establishing a living mutual relation between himself and them'. Thus, the essential element of genuine dialogue is 'seeing the other' or 'experiencing the other side' (Friedman 1955: 87). 'Experiencing' involves living through a common event from one's own standpoint as well as 'from the standpoint of the other'. This act, which Buber terms elsewhere 'creation' or a 'creative [...] exchange of glances', is 'the essence of all genuine love' (Friedman 1955: 88). Rukeyser's concluding poem to The Book of the Dead ends with the lines 'communication to these many men, / as epilogue, seeds of unending love'. Again, her poetics of meeting and dialogue - germinating in moments of what she too terms 'creative exchange' - result in and are resultant of an essential love that extends beyond the physical to a spirituality that binds humans to each other and to God.

Such inclusivity, stemming from the full use and awareness of the human senses, is evident between the workers and the poem's witness in 'Praise of the Committee', where the workers gather to become more than a Marxist collectivity (a concept Buber explicitly argued against), but a Buberian 'wholeness' (Friedman 1955: 201). The committee becomes a 'single force' as 'George Robinson holds all their strength together'. More than this however, the committee becomes a single human face, perceptive, giving and receptive in its look:

In this man's face

family leans out from two worlds of graves -

here is a room of eyes,

a single force looks out, reading our life.

(Rukeyser 2006: 82)

As witnesses, linked with the poet, and engaged in the act of reading the poem, we are called upon to respond to a human other that is in turn 'reading our life'. 'Praise of the Committee' is an example of Rukeyser's achievement throughout The Book of the Dead to create moments of proof of human, imaginative, creative exchange via the meeting and merging of the senses. Her understanding of poetry as an inclusive communication between poet, poem and witness relied on the predicate that poetry (and the poet) always intends towards another as equal. The look of the union body in this poem meets the gaze of the reader/witness, who is called upon, if not to act, at 
least to react. Within the structure of the poem, multiple voices emerge and merge, which not only wish to be heard, but, in the closing line of the poem, 'demand an answer': the alternating lyrical and documentary voice of the poet; the voices of various testimonies apparently quoted verbatim, read by the unifying voice of George Robinson. As readers, we are called upon to witness the poem as Rukeyser intended, with an air of responsibility that gives rise to a change in the self.

However, there remains one important element in the explication and employment of ethical responsibility and the understanding of 'community' that this essay has yet to address: the consideration of race. As I noted above, the Gauley Bridge disaster resulted in the deaths of hundreds of workers over half of them migrant and the majority of them African American. Martin Cherniack, in his book-length study of the disaster, The Hawk's Nest Incident (1986), drew on court hearing transcripts, interviews and private testimonies to ascertain that several of the corpses of black migrant workers were disposed of quickly and without proper burial by the company in charge of the tunnelling, Rinehart and Dennis, ${ }^{15}$ rendering it impossible to gauge with any real accuracy how many African Americans died as a consequence of working in the tunnel, although at its most conservative estimate, the figure is close to 600 (Cherniack 1986: 104). Rukeyser's own approach to the central issue of race and race relations in the town of Gauley Bridge and in the broader arena of capitalist commerce and industry during the Depression era is surprisingly muted. As Tim Dayton has also noted, although Rukeyser signals her understanding of the pivotal place of black experience in the disaster through the centrality of the poem 'George Robinson: Blues', a rather unsuccessful blues-lyric verse written in the voice of the key, black, figure at the hearings (the driller was actually called George Robison), 'it seems more correct to emphasise Rukeyser's relative muting of the racial element of the tragedy' (Dayton 2003: 73). Dayton attributes Rukeyser's decision to downplay the tensions between the white and black workers as well as the extreme exploitation of the African American migrants to two factors. Firstly, he believes Rukeyser's affiliations with the popular front led her to de-emphasize the racial dimension of the tragedy in favour of forging 'an alliance with a broad spectrum of nonreactionary elements in the country'. Secondly, Rukeyser's structuring the poems along spatial, rather than thematic, frameworks, helped to 'unite the local populace into a community' (Dayton 2003: 73-74). It is true that Rukeyser's figuring of the workingclass people of Gauley Bridge constitutes a unification that appears almost to ignore the tensions inherent in racial difference, and certainly to omit the class-based conflicts existent within the white community (Dayton 2003: 75). 'Praise of the Committee' especially conflates the voices of the oppressed into one synaesthetic whole: the sympathetic voice of Emma Jones joins with George Robinson's voice, his 'strength' as he 'holds' the community together and his 'look', which becomes the demanding, waiting, composite portrait of the populace.

For the purposes of this essay, then, which is concerned with the ways in which Rukeyser utilizes the human senses in an ethical philosophical approach to both the life of 'the people' (Rukeyser 2006: 80) and the life of poetry, it is not necessary to explore race relations further, largely because they are notably lacking in The Book of the Dead. What I can assert, in considering the role of race in a Buberian, sensorial analysis of the poems, is that Rukeyser's notion of community is closely aligned to that of Buber, expressed in his writings and
15. Rukeyser's poem 'The Cornfield' refers to this practice, although it does not allude to the colour of the bodies hastily buried: 'Buried, five at a time, / pine boxes, Rinehart \& Dennis paid him $\$ 55 /$ a head [...]'. 
16. Robison's testimony states that the dust blackened the white workers, so that none could tell the difference (Cherniack 1986; Dayton 2003: 53) public addresses at the beginning of the 1930s. Rukeyser's binding theme of convergence is again related in sensorial terms in the poem 'Gauley Bridge', where images of junctions, crossings, bridges and pathways find reflection in the intersecting looks of the separate people pictured in the tableau - looks that include that of 'the deserted Negro'. Rukeyser ends the poem with the somewhat inaccurate line: 'These people live here' (Rukeyser 2006: 78). In 'Praise of the Committee', 'these people' have forged a solid communal presence, although the absence of names for the 'Negroes' is notable:

Here are Mrs. Jones, three lost sons, husband sick,

Mrs. Leek, cook for the bus cafeteria,

the men: George Robinson, leader and voice,

four other Negroes (three drills, one camp-boy)

Blankenship, the thin friendly man, Peyton the engineer [...]

(Rukeyser 2006: 80)

Brought together by a common wish for justice via the bearing of witness and the speaking of testimony, this 'committee' aims at self-representation in both an ethical and juridical sense. Cherniack noted that once the death toll began to grow beyond easily concealable proportion, Rinehart and Dennis employed lawyers and doctors to effectively silence the afflicted workers and their families with small payouts and misdiagnoses of pneumonia (Cherniack 1986: 59, 11). Rukeyser's use of the workers' testimony quoted verbatim in several of the poems in The Book of the Dead appears to align her understanding of community with that of Buber. Writing in 1931 in an essay entitled 'Comments on the Idea of Community', Buber asserted,

The more a human group lets itself be represented in the determination of its common affairs and the more from outside, so much less does community life exist in it, and so much poorer in community does it become. [...] The primal hope of all history depends upon a genuine and, hence, thoroughly communally disposed community of the human race.

(Buber [1931] 2002: 243)

Moreover, Buber's wish for true community was founded on the belief of its requiring 'commonness of trouble, and only from this, commonness of salvation'. Such 'salvation' manifests itself, according to Buber, as a 'rebirth' of communal spirit, giving way to 'a changed world situation' (Buber 2002: 244-45). Again, Buber's influence, or at least the striking similarity in his thinking, seems clear in the thematic thread in The Book of the Dead of rebirth, especially in allusion to the Egyptian Book of the Dead, and in Rukeyser's belief that a poetics of witness has 'the capacity to produce change in existing conditions' (Rukeyser [1949] 1996: 178). The communality of the workers' situations is stressed by Rukeyser in an arresting image that underscores both her avoidance of the complexities of race relations in the disaster and her recourse to visual strategies: in 'George Robinson: Blues', she reverses Robison's recorded testimony of the blackening effect of the dust from the tunnel: ${ }^{16}$

As dark as I am, when I came out at morning after the tunnel at night, with a white man, nobody could have told which man was white.

The dust had covered us both, and the dust was white.

(Rukeyser 2006: 88) 
Rukeyser's decision to render the tunnel dust white was perhaps artistic (it glistens like 'snow' in other passages) and political: the 'commonness of trouble' in this tragedy is, after all, the power and greed of a 'white' capitalist corporation. Additionally, the visual and verbal play between the words 'whiteness' and 'witness' highlight the connections of the two across poetic, ethical and social constructions.

The portions of courtroom testimony included in The Book of the Dead provide the most obvious example of 'witness' - the 'tension of the law' that Rukeyser noted was an important element of the word. In the medical testimony laced throughout The Book of the Dead, the importance of visual capacity further joins the social to the individual. The transparency trope evident in the poet's use of the camera as metaphor is extended in Rukeyser's recourse to the X-ray images taken of those affected by the silicosis. These images develop Rukeyser's theme of probing discovery, rendering the invisible visible, and enabling us to behold both the destroyed workings of the human body and the destructive workings of the body politic. In "The Disease', Rukeyser repeats the testimony of an expert on dust diseases as he indicates the rapid progression of silicosis through three $\mathrm{X}$-ray images:

I would point out to you: these are the ribs;

this is the region of the breastbone;

this is the heart (a wide white shadow filled with blood).

Now, this lung's mottled, beginning, in these areas.

You'd say a snowstorm had struck the fellow's lungs.

[...]

Let us have the second.

Come to the window again. Here is the heart.

More numerous nodules, thicker, see, in the upper lobes.

You will notice the increase : here, streaked fibrous tissue - Indicating?

That indicates the progress in ten months' time.

And now, this year - short breathing, solid scars

[...]

Blood vessels shut. Model conglomeration.

What stage?

Third stage. Each time I place my pencil point:

There and there and there, there, there. ${ }^{17}$

(Rukeyser 2006: 86)

The internal human body made visible reveals scars similar to those of the 'murdering snow' Rukeyser notes earlier in the book to be covering the West Virginian landscape. As witness, we have travelled progressively deeper into the land, its story and its people, achieving an ultimate Buberian 'openness' and 'presentness'. We are drawn into the testimony as we are drawn further into the human body of the worker diagnosed. The 'pencil point' of the diagnostician finds its correlative in the recording tool of the witnessing poet, and this image of inscription within the body is central to Rukeyser's understanding of the Egyptian Book of the Dead, after which her poem series is named.

The streaks and mottled shadows visible on the X-rays and decrypted as silica damage correspond to the hieroglyphic inscriptions written on amulets and buried within the bodies of Egyptian mummies, thought to help convey
17. CP, 86. David Kadlec has offered a detailed and insightful reading of Rukeyser's use of $x$-ray images (1998: 23-47). He argues correctly of this passage that it 'elicits the human cost of Hawk's Nest Tunnel not through straight presentation, but through a poetic approximation of the spatial and temporal depths of modern medical visual technologies' 
18. One such incident is what was termed 'The Rukeyser Imbroglio'. The editors of Partisan Review attacked Rukeyser for her writing style and assailed her political poetics as 'fashionable' examples of 'bandwagon' jumping and patriotic'neoAmericanism' (R.S.P. 1943, 1944a, 1944b). F. O. Mattheissen, among others, wrote to the journal in Rukeyser's defence. the bodies of the dead through the underworld (Kadlec 1998). By interlacing the testimony of Mrs. Jones, a mother who has lost her family to silicosis, with quotations from the Egyptian Book of the Dead, Rukeyser ties the themes of witness, statement, judgment, power and passage. In 'Absalom', Shirley Jones, the youngest son to die of the disease, asks his mother to ensure that his chest is opened after his death and the cause of his illness exposed. Her testimony will facilitate 'the first in a line of lawsuits', extending Shirley's voice and image to touch other lives, and establishing a dialogue beyond death (Rukeyser 2006: 85). Providing a precedent for other families to follow, the Joneses act both as spiritual guides to the living and as protectors of the dead. Jones and his mother 'open out a way' for true dialogue, achieving a wholeness that renders the dead boy holy in his full awareness of alterity and self. The boy's body, his labour and the landscape in which he laboured and is buried are now within his control, as his influence extends as a conduit of communication, meeting and reconciliation:

\section{My heart my coming into being \\ [...] \\ I have gained mastery over my heart \\ I have gained mastery over my two hands \\ [...] \\ I open out a way over the water \\ I form a path between the Combatants}

(Rukeyser 2006: 84, 85, 100)

Utilizing and adapting incantations from the Egyptian Book of the Dead, Rukeyser demonstrates that via witness and dialogue, Shirley Jones' guiding ability to 'open' the way to the communication of truth via the opening of his own body associates him with the life-giving rivers first featured in 'The Road' and 'West Virginia'. The 'power' referred to in the latter poem as 'done by the dead' assumes new meaning in 'Absalom', and the spiritual 'opening' of Jones' passage into the afterlife corresponds with the renewing energy of the paths cut by the rivers through the countryside, 'like valleys, opening mines,/coming to life'.

In The Book of the Dead, therefore, Rukeyser travels a poetic path into the heart of human corruption and redemption via a route forged by natural, spiritual and historical forces. Her belief that 'no one sense is ever employed alone' guides a journey fed by the synaesthetic meeting-place of human beings, of modes of human consciousness and of communication (Rukeyser [1949] 1996: 134). 'Coming of age' in the 1930s, and fully engaged in various documentary and modern technological methods of representation, Rukeyser was well versed in Marxist conceptions of ideological production. Her radical politics, I have hopefully demonstrated, are evident in her 1938 poem series, as is her innovative figurative employment of new visual technologies. What is less remarked upon, and unfortunately often dismissed by other radical writers of the era and modern critics alike, is her religious, Jewish, mysticism, strongly aligned with Buberian philosophy. ${ }^{18}$ In a letter to the poet and editor Louis Untermeyer two years after the publication of The Book of the Dead, Rukeyser defined and defended her political-poetic stance:

I believe in poetry. I believe that the life of people and the life of poetry must ultimately mean the same thing, in the different terms involved. I believe in the life of the spirit generally walking the earth, against war, 
against slavery, for the giving of all the processes and inventions and art and technique of living. ${ }^{19}$
19. Letter dated 25 June 1940.

(Wald 2002: 303)

By developing a dialogism that is founded on social and ethical values, Rukeyser was able to open a route of investigation in The Book of the Dead that affirms human and poetic life, succeeding in meeting the other - economical, political, social, ontological - where both the Marxist and documentary movements often failed: with a full and reciprocal engagement of the physical and human senses.

\section{REFERENCES}

Agee, James ([1941] 2001), Let Us Now Praise Famous Men, London: Violette. Anderson, Sherwood (1935), Puzzled America, New York, London: Scribner.

Bourke-White, Margaret and Erskine Caldwell (1937), You Have Seen Their Faces, New York: The Viking Press.

Buber, Martin (1951), 'Society and the state', World Review (May) (New Series 27).

- (1956), I and Thou, in Will Herberg (ed.), The Writings of Martin Buber, New York: Meridian Books, pp. 43-62.

- (1992), On Intersubjectivity and Cultural Creativity, S. N. Eisenstadt (ed.), Chicago University Press.

(2002), 'Comments on the idea of community', in Asher D Biemann (ed.), The Martin Buber Reader, New York: Palgrave, pp. 243-246.

(2004), Between Man and Man, London and New York: Routledge.

Cherniack, Martin (1986), The Hawk's Nest Incident: America's Worst Industrial Disaster, New Haven and London: Yale University Press.

Dayton, Tim (2003), Muriel Rukeyser's The Book of the Dead, Columbia and London: University of Missouri Press.

Friedman, Maurice S. (1955), Martin Buber: The Life of Dialogue, London: Routledge and Keagan Paul Ltd.

Hatcher, Harlan (1938), 'The historical opportunities offered through the writers' program', Ohio Archaeological and Historical Quarterly, 47: 3, p. 247.

Kadlec, David (1998), 'X-ray testimonials in Muriel Rukeyser', Modernism/ Modernity, 5: 1, pp. 23-47.

Kalaidjian, Walter (Winter, 1991-92), 'Muriel Rukeyser and the poetics of specific critique: Rereading "The Book of the Dead" ', Cultural Critique, 20 , pp. $65-88$.

Kaufman, Janet (1999), ' "But not the Study": Writing as a Jew', in Anne F. Herzog and Janet E. Kaufman (eds), How Shall We Tell Each Other About the Poet? New York: Palgrave, pp. 45-61.

Marx, Karl (1981), Economic and Philosophic Manuscripts of 1844, London: Lawrence and Wishart.

Marx, Karl with Friedrich Engels (1998), The German Ideology including Theses on Feuerbach and the Introduction to the Critique of Political Economy, New York: Prometheus.

Mitchell, W. J. T. (1986), Iconology: Image, Text, Ideology, The University of Chicago Press.

Rabinowitz, Paula (1994), They Must be Represented: The Politics of Documentary, New York and London: Verso.

Rorty, James (1936), Where Life is Better: An Unsentimental American Journey, New York: Reynal and Hitchcock. 
R.S.P. (1943), 'Grandeur and misery of a Poster Girl', Partisan Review, 10, pp. $471-73$.

- (Winter, 1944a), 'The Rukeyser Imbroglio', Partisan Review, 11, pp. 125-29.

(Spring, 1944b), 'The Rukeyser Imbroglio (cont'd)', Partisan Review, 11, pp. 217-18.

Rukeyser, Muriel ([1949] 1996), The Life of Poetry, Ashfield, MA: Paris Press. (April 1961), American Judaism, 13.

- (2006), The Collected Poems of Muriel Rukeyser, Janet E. Kaufman and Anne F. Herzog (eds), Pittsburgh, PA: University of Pittsburgh Press.

Stott, William (1973), Documentary Expression and Thirties America, New York: Oxford University Press.

Wald, Alan (2002), Exiles from a Future Time: The Forging of the Mid-Twentieth Century Literary Left, Chapel Hill and London: The University of North Carolina Press.

Wechsler, Shoshana (1999), 'A mat(t)er of fact and vision: The objectivity question and "The Book of the Dead" ', in Anne F. Herzog and Janet E. Kaufman (eds), How Shall We Tell Each Other of the Poet? New York, pp. 226-40.

\section{SUGGESTED CITATION}

Gander, C. (2011), 'The senses of Muriel Rukeyser's The Book of the Dead', European Journal of American Culture 30: 3, pp. 175-194, doi: 10.1386/ ejac.30.3.175_1

\section{CONTRIBUTOR DETAILS}

Catherine Gander completed her Ph.D. at King's College London in 2009 and now lectures in American literature and culture at the University of Nottingham. Her book Muriel Rukeyser and the Sources of Documentary is being prepared for publication, and she has published on American poetry, literaryphilosophical relations and visual culture. She is currently working on a new imagetext research project: tracing and examining the interrelations of the written word and the visual image in modern American culture.

Contact: The University of Nottingham, University Park, Nottingham, NG7 2RD, UK.

E-mail: catherine.gander@nottingham.ac.uk 